Meta

Journal des traducteurs

Translators' Journal

\title{
Betrayal - Vice or Virtue? An Ethical Perspective on Accuracy in Simultaneous Interpreting
}

\section{Kilian G. Seeber et Christian Zelger}

Volume 52, numéro 2, juin 2007

URI : https://id.erudit.org/iderudit/016071ar

DOI : https://doi.org/10.7202/016071ar

Aller au sommaire du numéro

Éditeur(s)

Les Presses de l'Université de Montréal

ISSN

0026-0452 (imprimé)

1492-1421 (numérique)

Découvrir la revue

Citer cet article

G. Seeber, K. \& Zelger, C. (2007). Betrayal - Vice or Virtue? An Ethical Perspective on Accuracy in Simultaneous Interpreting. Meta, 52(2), 290-298. https://doi.org/10.7202/016071ar
Résumé de l'article

L'interprétation simultanée de conférence représente une tâche linguistique hautement complexe et suppose un processus très délicat de transfert d'informations. Par conséquent, la notion de vérité est d'une importance capitale et lorsqu'on l'applique à l'interprétation simultanée, elle implique une transposition fidèle du message initial. Malgré cela, l'analyse des transcriptions et des corpus semble parfois suggérer que les interprètes trahissent l'orateur en modifiant délibérément l'original. Nous n'excluons certes pas l'existence de tels cas ; toutefois, nous affirmons que ce qui peut être perçu comme une mauvaise interprétation peut s'avérer une transposition fondée sur une décision éthique valable.

Dans cet article, nous examinons de plus près ces occurrences et tentons de mettre en lumière les motivations potentielles sous-tendant les décisions et les actions des interprètes. À l'aide d'exemples d'interprétation de la vie réelle, nous étudions la prestation de l'interprète et testons d'un point de vue déontologique et téléologique ce qui, à première vue, pourrait ressembler à une inexactitude.

Sur la base de cette analyse, nous proposons un modèle selon lequel l'interprète utilise trois éléments principaux du message, les éléments verbaux, sémantiques et intentionnels, pour offrir une transposition exacte de l'original, autrement dit une « interprétation fidèle ».
Ce document est protégé par la loi sur le droit d'auteur. L'utilisation des services d'Érudit (y compris la reproduction) est assujettie à sa politique d'utilisation que vous pouvez consulter en ligne.

https://apropos.erudit.org/fr/usagers/politique-dutilisation/ 


\title{
Betrayal - Vice or Virtue? An Ethical Perspective on Accuracy in Simultaneous Interpreting
}

\author{
KILIAN G. SEEBER \\ Université de Genève, Genève, Suisse \\ kilian.seeber@eti.unige.ch \\ CHRISTIAN ZELGER \\ Freelance consultant and Editor of Omegaminus \\ chzelger@chrizia.com
}

\section{RÉSUMÉ}

L'interprétation simultanée de conférence représente une tâche linguistique hautement complexe et suppose un processus très délicat de transfert d'informations. Par conséquent, la notion de vérité est d'une importance capitale et lorsqu'on l'applique à l'interprétation simultanée, elle implique une transposition fidèle du message initial. Malgré cela, l'analyse des transcriptions et des corpus semble parfois suggérer que les interprètes trahissent l'orateur en modifiant délibérément l'original. Nous n'excluons certes pas l'existence de tels cas; toutefois, nous affirmons que ce qui peut être perçu comme une mauvaise interprétation peut s'avérer une transposition fondée sur une décision éthique valable.

Dans cet article, nous examinons de plus près ces occurrences et tentons de mettre en lumière les motivations potentielles sous-tendant les décisions et les actions des interprètes. À l'aide d'exemples d'interprétation de la vie réelle, nous étudions la prestation de l'interprète et testons d'un point de vue déontologique et téléologique ce qui, à première vue, pourrait ressembler à une inexactitude.

Sur la base de cette analyse, nous proposons un modèle selon lequel l'interprète utilise trois éléments principaux du message, les éléments verbaux, sémantiques et intentionnels, pour offrir une transposition exacte de l'original, autrement dit une «interprétation fidèle».

\footnotetext{
ABSTRACT

Simultaneous conference interpreting represents a highly complex linguistic task and a very delicate process of information transfer. Consequently, the notion of truth - which applied to the field of simultaneous interpreting entails an accurate rendition of the original message - is of pivotal importance. In spite of that, an analysis of experimental transcripts and corpora sometimes seems to suggest that interpreters betray the speaker by deliberately altering the original. While we cannot exclude that such instances do exist, we argue that sometimes what looks like betrayal may in fact be a rendition based on a sound ethical decision.

In this paper we take a closer look at these situations in an attempt to shed more light on the potential motivations underlying the interpreter's decisions and actions. Using examples from real life interpreting situations, we take the interpreter's output and put what at first sight appears to be a betrayal of the speaker on the ethical test bench, both from a deontological and a teleological perspective.

Based on this analysis we propose a model suggesting that the interpreter uses three principal message components, verbal, semantic and intentional, in order to come up with an accurate interpretation of the original, which we call "truthful rendition."
}

\section{MOTS-CLÉS/KEYWORDS}

simultaneous interpreting, philosophy, ethics, accuracy, betrayal 


\section{Introduction}

Simultaneous conference interpreting is a relatively young profession. The first experiments with this new technique of real time oral translation took place at the ILO in Geneva in the late 1920s, although the Nuremberg trials after World War II are often considered the cradle of SI (simultaneous interpreting) as we know it today (Gaiba 1998).

Partly due to the creation of international organizations and bodies such as the League of Nations (predecessor of the UN) and the European Coal and Steel Community (which would later evolve into the EU) and their need for multilingual communication, the profession of conference interpreting has experienced a steady growth. After little more than 50 years, SI has achieved a relatively high level of professionalism. Many schools or university departments where the trade or art of interpreting is taught are almost as old as the profession itself, such as Geneva (ETI, Ecole de Traduction et d'Interprétation), founded in 1941, or Paris (ESIT, Ecole Superieure des Interprètes et Traducteurs) in 1957. CIUTI (Conférence des instituts universitaires de traduction et d'interprétation) has almost 30 member institutions, and AIIC (Association international des interpretes de conférence), the only international professional association for conference interpreters, comprises over 2700 members worldwide.

With the professionalisation of simultaneous interpreting the expectations both of users and employers have risen considerably. Interpreters are required to undergo formal training and pass tests to gain access to (i.e., get "accredited" with) certain international organizations (e.g., the EU or the UN). Furthermore, they are expected to perform in an increasingly (cognitively) demanding environment. A fundamental aspect of this performance is the concept of being faithful to the speaker. In other words, the interpreter is expected to accurately relay the message of the speaker, not his own.

The aim of this paper is to take a closer look at the notion of accuracy in simultaneous conference interpreting, but to do so from an ethical rather than linguistic perspective. As a matter of fact, we believe that certain instances which from a purely linguistic point of view could be construed as betrayal may in fact be the result of a sound ethical decision if examined from a philosophical angle.

\section{Conference interpreting and ethics}

It is important to preface our analysis by limiting its scope to the realm of simultaneous conference interpreting, a particular form of interpreting performed in real time, i.e., with a team of interpreters located in the conference room in soundproof booths, listening to the original message over headphones and simultaneously rendering that message through a microphone in the target language.

Such a setup has certain repercussions on the communication process, as the intermediary (the interpreter) is physically removed (usually relegated to the back of the room), and thus unable to interrupt the speaker or ask for clarification (as he can do when working in consecutive mode, where he is sitting close to the speaker and his audience).

So first class interpreters are vital and the best are also a little bit creative. Some are quite happy to improve the speakers' words, even correct them where necessary [...] (Robbins 2004). 
The idea of conference interpreters changing the original message at their discretion by adding to or subtracting from it seems to be as popular as it is persistent (cf. Robbins 2004). This begs the question about whether there are general guidelines governing professional interpreters' performance in order to ensure that they do indeed render the original message. One would expect these guidelines to be enshrined in the code of ethics of the international association of conference interpreters. ${ }^{1}$ This document, first drafted in 1953 with the foundation of the organization and updated several times (most recent update 1994) addresses several issues pertaining to the ethical conduct of interpreters. However, whereas the need for the interpreter's strictest secrecy, confidentiality and collegiality - to mention just a few - are postulated explicitly, no reference is made to the requirement of the interpreter faithfully relaying the original message. This is particularly intriguing as other (national, regional or specialized) professional organizations for interpreters stress the importance of accuracy (e.g. NAD-RID, ${ }^{2} \mathrm{NAJIT}^{3}$ ). The distinctiveness of both sign language interpreting and legal interpreting only partially explains the particular importance these organisations seem to attribute to the notion of accuracy in interpreting. Professionalization in sign language interpreting is coming about at a much slower pace than in conference interpreting, particularly in community settings.

Consequently, it has not been unusual for untrained bilinguals to be called upon to interpret for their friends and families. This means that the dividing line between interpreter and speaker often blurred as the interpreter, i.e., the speaker's voice, turned into an advocate who champions the speaker's interests (Seeber 2002a,b,c). The legal setting, on the other hand, requires particular attention to accuracy, as judge and jury assess the witnesses both on the grounds of what they say and how they say it (Mikkelson 1995; 2000).

What is more, the notion of accuracy has been a perennial issue in the literature on written translation, where several authors (Jakobson 1959, Nida 1964, Toury 1980, Snell-Hornby 1988, Vermeer 1989, Baker 1992, Koller 1992, Pym 1992, Chesterman 1997; 2001, Venuti 1998 etc.) have suggested their own notion of accuracy, fidelity, equivalence, correspondence or similarity, qualifying it with at least as many adjectives (formal, dynamic, grammatical, textual, pragmatic, etc.). The literature on the much younger discipline of simultaneous interpreting has addressed the issue of inaccuracy mainly from the perspective of interpreting mistakes (Barik 1969, Kopczynski 1980) and interpreting strategies (Sunnari 1995, Wadensjö 1998). However, none of these authors considered a scenario in which the interpreter deliberately alters the original message where such alteration is not imposed by constraints such as time or mental resources. We set out to explore instances in which the interpreter chooses to alter, truncate or omit parts of the message for ethical reasons.

\section{From accuracy to a truthful rendition}

The dictionary ${ }^{4}$ defines accuracy as "freedom from mistake or error" or "degree of conformity of a measure to a standard or a true value" (Webster's 1993). Truth, on the other hand, is widely accepted as a basic value in our society. To the philosopher, truth is "the quality of those propositions that accord with reality, specifying what is in fact the case" (Audi 1995: 812). In SI this reality consists of the message that the interpreter is asked upon to convey. The thorny issue is to specify what the notion of message entails. 
We have seen before that SI is the transfer of a spoken message into another language. As all languages are made up of individual lexemes, an overly simplistic view of SI could see the process as a transposition of these building blocks from the source language into the target language. Such an exercise could easily be performed by a computer (even more efficiently and rapidly than by any human being) but its shortcomings are obvious. Indeed, even at the dawn of the third millennium computer programs are not able to produce satisfactory results given that a word for word translation of the original very often fails to capture and/or render the meaning in the target language. Consequently, semantic aspects must be taken into account in order to offset the constraints imposed by a purely literal approach. This means then that the message is not solely contained in the building blocks of a proposition $\mathrm{P}$, but emerges from their interaction. Finally, given certain pragmatic constraints, the interpreter may look beyond the words and their combined meaning and rely upon a third message component, i.e., the underlying speaker's intent.

We see therefore that the message comprises a verbal, a semantic and an intentional component. According to the rationale laid out at the beginning of this section, an accurate interpretation - which we will refer to as truthful rendition - is one that considers all three message components. When these three components converge, the analysis based on one of them yields the same result as one including all three constituents. Whenever the analysis of the three message components produces incongruent results, however, the interpreter must choose on which message components to base his interpretation.

\section{When heads of states become traffic cops}

The following real-life example should help elucidate our notion of a truthful rendition in simultaneous interpreting. The transcript below is taken from an international conference featuring several European and African heads of state and government for which simultaneous interpretation into four languages is provided. The master of ceremony, an Italian television talk show host, appears to be new to the diplomatic and political arena. After the fervent intervention of the keynote speaker (an African head of state) who passionately describes the deplorable situation of children in his country, the MC addresses him as follows (figure 1).

Interestingly, a spot survey revealed that none of the interpreters working at the time rendered the last sentence (personal communication). But what are the reasons driving the interpreter to apparently betray the speaker?

It could be argued that likening a head of state, i.e., a high dignitary, to a traffic cop is offensive regardless of the cultural background of the addressee. We believe the interpreter realized that it cannot possibly be the MC's intention to insult one of the guests of honor. This is why beyond the verbal and semantic message components the interpreter decided to integrate the third component, i.e., the intention of the speaker. As we already pointed out, this decision taken by the interpreter is the result of an ongoing monitoring process, therefore an action essential for his job. We will briefly explore what philosophical theories such actions can be based upon. 
FIGURE 1

Transcript

O: Ma quanto è bravo. Grazie, grazie per il suo bellissimo intervento. Mi ha commosso.

G: [] how much is good.Thanks, thanks for the your wonderful contribution. Me has touched.

I: What a great speaker. Thank you for your wonderful contribution. I was touched.

O: Volevo chiederle una cosa. Lei ha degli antenati Italiani? Perché parla con le mani....

G: I wanted to ask you one thing.You have some ancestors Italian?Because you talk with the hands...

I: I wanted to ask if you had Italian ancestors, because you talk with your hands...

O: ...se fosse in Italia potrebbe fare il poliziotto e dirigere il traffico.

G: ...if you were in Italy you could be the cop and direct the traffic.

I: [ ...]

\section{Teleological vs. deontological theories of ethics}

Ethics, the study of morality, can be divided into the general study of goodness, the general study of right action, applied ethics, meta-ethics, moral psychology, and metaphysics of moral responsibility (Audi 1995: 244). Moreover, ethics can have different objects of study, from values and norms to intentions and actions or consequences. As an action, SI is also subject to ethical scrutiny.

Given that our goal is to elucidate the notion of accuracy in SI we will assess the ethical implications of SI as an action. There are two distinct possibilities of performing such assessment, relying on two distinct types of ethical theories, i.e., teleological and deontological theories. Teleological theories postulate the ethical examination of an action's consequences. In other words, according to teleological theories, an action is deemed good (thus obligatory) whenever its consequences are good. This raises the issue about whom the consequences of an action are good for. Depending on the beneficiary of an action we distinguish between egoism, altruism and utilitarianism, of which the latter principle is most prominent in current philosophical debates. According to utilitarianism, a good action is one generating the greatest happiness for the largest possible number of people (cf. Audi 1995: 494ff). Deontological theories, on the other hand, do not focus on the consequences of an action, but rather on their intention. They revolve around principles of justice and honesty and the intention of the action's author.

Using the above example, we can draw some tentative conclusions with regard to the interpreter's action, more specifically his decision (D) to change the proposition $(\mathrm{P})$ both verbally (v) and semantically (s), to implement the intentional (i) component. 


\subsection{Teleological ethics}

We have seen that utilitarian (teleological) ethics considers an action to be good when the consequences contribute to the attaining of a goal shared by the largest number of people concerned. In our example, this would include the speakers, the listeners, the interpreters, in other words all conference participants. The interpreter has to assess what consequences Di (i.e., the decision to base the interpretation mainly on the perceived intentional message component) entails, and based on this assessment whether Di is good.

Opting for Di may entail the following consequences. Firstly, the rendition will depart further from the verbal and semantic information contained in the source text. Whereas some interpreters and interpreter researchers may view this as a betrayal of the speaker, we see the task of the interpreter to convey the message, in other words all three components. Secondly, in the above example, the interpreter's decision most likely avoids an insult that was never meant to be. Having said that, the interpreter can never be absolutely sure about any speaker's intention, nor about the quantity and quality of the consequences his actions entail.

If, on the other hand, the interpreter opts for Ds, the decision to draw only on verbal and semantic components of the message, the following scenario is likely to occur. Firstly, the rendition will be semantically close to the original, and therefore an adequate interpretation according to some SI scholars. Secondly, in the above example, a semantically close interpretation of the message would probably have been perceived as an insult. Taking this thought a bit further, we could well imagine a diplomatic incident, with the MC getting sacked and the African dignitary opting for an early departure.

The main problem for the interpreter working simultaneously of course is time or the lack thereof. Indeed he only has a split second to contemplate the possible consequences of his actions, which constitutes the very basis on which he answers the question about whether Di is good or not.

\subsection{Deontological ethics}

Unlike teleological ethics, which tries to answer the above question based on its consequences, deontological theories attempt to answer the same question by assessing the reasons for the decision without regard for its effects.

If the interpreter in our example decides not to take into account the intentional component of the message it may be because as an interpreter he does not feel responsible for the message's content or does not dare guess the speaker's objective. He may take this decision because he does not believe he can accurately guess the speaker's true intention, but wants to perform to the best of his abilities. Thus from a purely deontological perspective in the above mentioned example, Ds is good, even if the African head of state decides to leave the conference early because he feels insulted.

It is not our intention to argue in favor of one or the other ethical position, particularly because all ethical decisions draw on both factors, intentions and consequences (e.g., a good intention may be motivated by an assessment of the potential consequences of a particular action). In fact, we believe it is up to each and every interpreter to make that decision. What we do want to point out, however, is that the 
choice among Dv, Ds or Di depends on a variety of considerations. This is why what on the surface looks like a betrayal of the speaker, may actually be an ethically justified interpretation of the original.

\section{The VSI model of truthful rendition in simultaneous interpreting}

In the preceding discussion we underscored the importance of three message components when attempting to produce a truthful rendition. We therefore propose the following model which we call the VSI model of truthful rendition in simultaneous interpreting.

We argued that any source message consists of three components (verbal, semantic and intentional), and that the interpreter's task becomes particularly delicate when the three don't appear to be congruent. In that case the interpreter has to decide which of the message components to principally rely on ( $\mathrm{Dv}$, Ds or $\mathrm{Di}$ ) so as to attain a truthful rendition. Our model (figure 2) is merely a simplified visualization of the factors enabling the interpreter to produce a truthful rendition of the original. It shows that the farther the interpreter moves away from verbal information, the more he needs to complement the message with semantic and intentional components. It is important to point out that the original message always contains all three levels of information, verbal, semantic and intentional. However, it is up to the interpreter to assess the amount of each kind of information he chooses or needs to use in order to attain the goal of a truthful rendition.

FIGURE 2

The VSI model

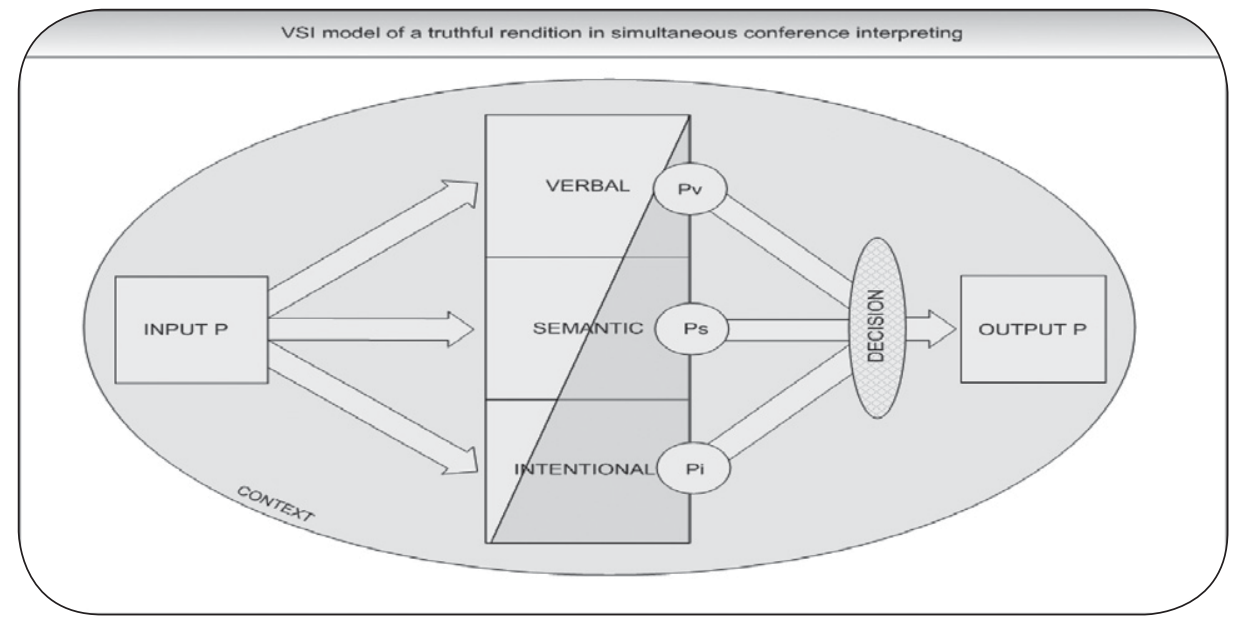




\section{Conclusion}

In his handbook for the interpreter, Herbert points out that " $[t]$ he conference interpreter is an assistant whose intelligent contribution is an indispensable factor in any international gathering" and goes on to say that " $\mathrm{t}]$ he interpreter should never forget that the immediate and essential object of his work is to enable his audience to know accurately what the speaker intended to convey, and to make on the audience the impression which the speaker wishes to make." (Herbert 1956: 25). Birse, one of Gorbachev's personal interpreters, says, "accuracy in translation was of vital importance" immediately qualifying the statement by adding that "sometimes a totally different word or phrase served better as giving the precise meaning and intention of the speaker who was thinking aloud in his own language" (1967: 108). It appears, thus, as though both Herbert's and Birse's early notions of accuracy are compatible with our definition of a truthful rendition.

We have seen in our example that the interpreter chooses not to interpret a particular phrase probably feeling that - although perhaps an attempt at humor - it is inadequate. But does the interpreter have the right and/or the authority to do that? What we cannot do and do not want to do is to argue in favor of giving the interpreter a blank check to modify the original message at his discretion. After all, interpreters are to be transmitters, not holders of information (cf. Neumann-Solow 1981), and although the VSI model describes communication processes the interpreter is regularly confronted with, it does not give any indication as to which course of action is most appropriate to achieve a truthful rendition of the original. The latter entails a decision by each and every interpreter which may be based on deontological or teleological considerations or both. It is when the interpreter alters the message in spite of an apparent congruence among the three message components that he is likely to betray the speaker.

Amongst the difficulties of making an ethical decision leading to a truthful rendition are the constraints under which the simultaneous interpreter performs his task. Stress, lack of time, high demands on cognitive resources are all factors that render ethical decision-making extremely difficult, which is why these issues should already be addressed during interpreter training as well as by professional interpreters whilst not in the booth. This would then enable them to react more rapidly and in line with ethical principles when faced with the situation in real life.

\footnotetext{
NOTES

1. <http://www.aiic.net>.

2. National Association for the Deaf - Registry of the Interpreters for the Deaf.

3. National Association of Judiciary Interpreters and Translators.

4. Merriam Webster Dictionary, 2003.
}

\section{REFERENCES}

Audi, R. (1995): The Cambridge Dictionary of Philosophy, Cambridge, Cambridge University Press.

BAKer, M. (1992): In Other Words: A Coursebook on Translation, London, Routledge.

BARIK, H.C. (1969): A Study of Simultaneous Interpretation, unpublished thesis, University of North Carolina at Chapel Hill.

Birse, A.H. (1967): Memoirs of an Interpreter, London, Joseph. 
Chesterman, A. (1997): Memes of Translation: The spread of ideas in translation theory, Amsterdam, John Benjamins.

Chesterman, A. (2001): "Proposal for a Hieronymic Oath,” The Translator 7-2, p. 139-154.

GaibA, F. (1998): The Origins of Simultaneous Interpretation: The Nuremberg Trial, Ottawa, University of Ottawa Press.

Jakobson, R. (1959): "On Linguistic Aspects of Translation," in Brower, R.A. (ed.), On Translation, Cambridge, Harvard University Press.

KolLer, W. (1992): Einführung in die Übersetzungswissenschaft. Heidelberg, Wiesbaden, Quelle and Meyer.

Kopczynski, A. (1980): Conference Interpreting: Some linguistic and communicative problems, unpublished doctoral dissertation, University of Poznan.

Mikkelson, H. (1995): "On the Horns of a Dilemma: Accuracy vs. brevity in the use of legal terms by court interpreters," in Marshall, M. (ed.), Translation and the Law, ATA Scholarly Monograph Series VIII, Amsterdam/Philadelphia, John Benjamins.

Mikkelson, H. (2000): "Interpreter Ethics: A review of the traditional and electronic literature," Interpreting 5-1, p. 49-56.

Neumann Solow, S. (1981): Sign Language Interpreting: A basic resource book, Maryland, The National Association of the Deaf.

Nida, E. (1964): "Principles of Correspondence," in Venuti, L. (ed.), The Translation Studies Reader, London: Routledge.

Pyм, A. (1992): Translation and Text Transfer: An essay on the principles of intercultural communication, Frankfurt am Main, Peter Lang.

Roвbins, J. (2004): “Breaking the Language Barrier," BBC Radio 4, 24.01.2004.

Seeber, K.G. (2002a): “Das Dolmetschen im medizinischen Bereich (Teil I),” Das Zeichen 16-59, p. $98-115$.

Seeber, K.G. (2002b): “Das Dolmetschen im medizinischen Bereich (Teil II),” Das Zeichen 16-60, p. 256-275.

Seeber, K.G. (2002c): “Das Dolmetschen im medizinischen Bereich (Teil III)," Das Zeichen 16-61, p. 414-423.

Snell-Hornby, M. (1988): Translation Studies: An integrated approach, Philadelphia, Benjamins.

SunNARI, M. (1995): "Processing Strategies in Simultaneous Interpreting: 'saying it all' vs. synthesis," in Tommola, J. (ed.), Topics in Interpreting Research, Turku, University of Turku.

Toury, G. (1980): In Search of a Theory of Translation, Tel Aviv, The Porter Institute for Poetics and Semiotics.

Venuti, L. (1998): The Scandals of Translation: Towards an ethics of difference, London, Routledge.

Vermeer, H. (1989): "Skopos and Commission in Translational Activity," Venuti, L. (ed.), The Translation Studies Reader, London, Routledge.

WAdEnsjö, C. (1998): Interpreting as Interaction, London and New York, Longman. 